\title{
Efektifitas Komunikasi Melalui Komunikasi Primer Dan Sekunder Dalam Pembelajaran PAI Di SMP Negeri 2 Luyo Kecamatan Luyo Kabupaten Polewali Mandar
}

\author{
Fadly Yusuf Aco \\ Fakultas Tarbiyah dan Ilmu Keguruan \\ Institut Agama Islam DDI Polewali Mandar \\ Jl. Gatot Soebroto Kelurahan Madatte Kecamatan Polewali Kab. Polewali Mandar
}

\begin{abstract}
ABSTRAK
Penelitian ini bertujuan untuk mengetahui efektifitas komunikasi primer dan komunikasi sekunder dalam pembelajaran PAI di SMP Negeri 2 Luyo Kecamatan Luyo Kabupaten Polewali Mandar. Jenis penelitian ini adalah penelitian deksriptif dengan pendekatan kualitatif dan juga merupakan penelitian lapangan (field reseacrh). Adapun yang menjadi subjek penelitian ini adalah Guru PAI dan peserta didik di SMP Negeri 2 Luyo Kecamatan Luyo Kabupaten Polewali Mandar. Jenis data yang dikumpulkan adalah data primer dan sekunder. Metode pengumpulan data yang digunakan adalah metode observasi, wawancara dan telaah dokumen. Data-data yang telah dikumpulkan selanjutnya dianalisis dengan teknik analisis deskriptif kualitatif pola interaktif dengan aktivitas data reduction (reduksi data), data display (penyajian data), dan conclusion drawing/verification (penarikan kesimpulan/verifikasi.

Hasil penelitian menunjukkan bahwa komunikasi primer yang terjadi dalam pembelajaran PAI di SMP Negeri 2 Luyo Kecamatan Luyo Kabupaten Polewali Mandar adalah terlaksana secara efektif yang ditandai dengan adanya proses: (1) Guru menjelaskan materi pelajaran dengan bahasa yang mudah dipahami; (2) Memberikan motivasi kepada peserta didik; (3) Guru kreatif dalam tata kelas; (4) Guru bersikap ekspresif sebagai penguat komunikasi; dan (5) Komunikasi yang dua arah. Komunikasi sekunder yang terjadi dalam pembelajaran PAI di SMP Negeri 2 Luyo Kecamatan Luyo Kabupaten Polewali Mandar telah terlaksana secara efektif yang ditandai dengan: (1) Guru menggunakan power point sebagai alat bantu dalam komunikasi; (2) Tersedianya buku paket yang memadai sehingga dapat digunakan oleh guru dan peserta didik; dan (3) Adanya penggunaan LKS dalam proses pembelajaran.
\end{abstract}

Kata Kunci: Efektifitas Komunikasi Primer, Komunikasi Sekunder, dan Pembelajaran PAI

\section{PENDAHULUAN}

Pendidikan tidak dapat dipisahkan dari komunikasi, karena pada hakikatnya proses pembelajaran adalah proses komunikasi, yaitu penyampaian pesan dari pengantar ke penerima. Pesan yang disampaikan berupa isi/ajaran yang dituangkan ke dalam simbol-simbol komunikasi, baik verbal (kata-kata dan tulisan) maupun non verbal.

Komunikasi merupakan aktivitas dasar manusia, karna manusia adalah makhluk sosial maka dengan berkomunikasi manusia akan dapat berhubungan satu sama lain dalam kehidupan sehari-hari, 
dan tidak ada manusia yang tidak terlibat komunikasi. Komunikasi yang dilakukan secara tepat dan baik tentunya akan menunjukkan hasil yang sesuai dengan harapan tetapi, jika komunikasi tidak berjalan baik maka akan membawa efek negatif yaitu dapat menimbulkan konflik atau masalah. ${ }^{1}$

Effendi merumuskan komunikasi sebagai proses pernyataan antar manusia. Hal yang dinyatakan itu adalah pikiran atau perasaan seseorang kepada orang lain dengan menggunakan bahasa sebagai alat penyalurnya. Dalam bahasa komunikasi, perntaan disebut sebagai pesan (message), orang yang menyampaikan pesan disebut sebagai komunikator (communicator). Sedangkang orang yang menerima pernyataan disebut sebagai komunikan (communicate). Komunikasi berarti proses penyampaian pesan oleh komunikator kepada komunikan. ${ }^{2}$ Dalam proses pembelajaran, guru berperan sebagai komunikator dan siswa sebagai komunikan.

Kunci utama komunikasi di kelas terletak di tangan guru, betapa pun pandai dan luas pengetahuannya, kalau tidak mampu mengkomunikasikan pikiran, pengetahuan, dan wawasan, tentu tidak akan mampu memberikan transformasi pengetahuannya kepada siswa. Oleh karena itu, kemampuan komunikasi dalam dunia pendidikan sangat penting artinya. Hampir $80 \%$ aktivitas guru di ruang kelas adalah komunikasi, baik verbal maupun non verbal, maka guru menjadi pihak yang bertanggung jawab untuk menciptakan komunikasi yang efektif dalam proses pembelajaran demi mencapai tujuan pembelajaran. ${ }^{3}$

Adakalanya siswa tidak mampu menafsirkan pesan disampaikan oleh guru, bukan karena guru tidak menguasai materi pelajaran tetapi karena komunikasi yang terjadi kurang baik. Terkait dengan proses pembelajaran, komunikasi dikatakan efektif jika pesan yang dalam hal ini adalah materi pelajaran dapat diterima dan dipahami, serta menimbulkan umpan balik yang positif dari siswa. ${ }^{4}$ Selain itu, komunikasi yang efektif dilaksanakan secara tatap muka antara guru dan siswa sehingga terjadi komunikasi dua arah.

Komunikasi dua arah yaitu apabila siswa bersikap responsif, mengetengahkan pendapat atau mengajukan pertanyaan, diminta atau tidak diminta. Jika siswa pasif saja, dalam arti kata hanya mendengarkan tanpa ada gairah untuk mengekspresikan suatu pernyataan atau pertanyaan maka sekalipun komunikasi itu bersifat tatap muka tetap saja komunikasi yang terjadi hanya satu arah sehingga komunikasi itu tidak efektif. ${ }^{5}$

Dalam pembelajaran Pendidikan Agama Islam (PAI) di SMP Negeri 2 Luyo Kecamatan Luyo Kabupaten Polewali Mandar, komunikasi yang terjadi masih satu arah. Hal ini dikarenakan hanya guru yang aktif dalam menjelaskan, sedangkan siswa hanya mendengarkan lalu mencatat. Hal tersebut akan berdampak kurang baik bagi siswa, yaitu siswa menjadi jenuh dan tidak tertarik dalam mengikuti pembelajaran. Komunikasi satu arah terjadi karena guru tidak melakukan inovasi dalam pembelajaran. Guru hanya menggunakan satu metode saja dalam setiap pembelajaran, yaitu ceramah. Metode ceramah memang tidak dapat dipisahkan dari proses pembelajaran, oleh karena itu penggunaannya harus diimbangi dengan metode yang lain sehingga siswa tidak jenuh.

\footnotetext{
${ }^{1}$ Ngainun Naim, Dasar-Dasar Komunikasi Pendidikan (Jogjakarta: Ar-Ruzz Media, 2011), h. 27-28.

${ }^{2}$ Onong Uchjana Effendy, Ilmu Teori dan Filsafat Komunikasi (Bandung: CA Publisher, 2010), h. 28.

${ }^{3}$ Ngainun Naim, Dasar-Dasar Komunikasi Pendidikan, h. 27-28.

${ }^{4}$ Abdul Majid, Strategi Pembelajaran (Cet. 3; Bandung: Remaja Rosdakarya, 2014), h. 292.

${ }^{5}$ Yudhi Munadi, Media Pembelajaran Sebuah Pendekatan Baru (Jakarta: Gaung Persada Press, 2012), h. 10.
} 
Komunikasi yang biasa dilakukan guru dan siswa adalah komunikasi verbal. Sebenarnya, pada saat melakukan komunikasi, bukan hanya menyampaikan pesan yang bersifat verbal melainkan juga menyampaikan pesan non verbal. Komunikasi verbal dan non verbal termasuk dalam komunikasi primer. Dalam komunikasi pembelajaran, biasanya komunikasi non verbal tidak banyak mendapatkan perhatian. Sementara hasil penelitian menunjukkan bahwa komunikasi non verbal memberi dampak signifikan dalam komunikasi guru dan siswa. Sebuah riset yang dilakukan oleh Calero yang dikutip dari Iriantara dan Usep menunjukkan bahwa pesan antar individu disampaikan melalui tubuh sebesar 55\%, melalui suara sebesar 38\% termasuk infleksi, intonasi dan volume, dan melalui kata-kata atau ucapan sebesar 7\%. ${ }^{6}$ Dari riset tersebut dapat terlihat bahwa berkomunikasi melalui tubuh menempati nilai tertinggi, sehingga dapat disimpulkan jika komunikasi non verbal harus menjadi perhatian bagi guru. Agar terciptanya pembelajaran yang efektif, guru harus memperhatikan setiap detail komunikasi baik verbal maupun non verbal (komunikasi primer) serta komunikasi sekunder (media).

Mengingat pentingnya komunikasi dalam pembelajaran, maka sangat diperlukan keterampilan komunikasi yang baik oleh guru dan siswa sehingga tujuan pembelajaran yang telah ditentukan akan mudah tercapai, baik tujuan pembelajaran dari aspek kognitif, afektif, maupun psikomotorik. Untuk itu penelitian ini dilakukan untuk melihat efektifitas komunikasi yang terjadi dalam proses pembelajaran, terutama efektifitas komunikasi primer dan efektifitas komunikasi sekunder. Karena itu, penulis memandang perlu untuk melakukan penelitian dengan judul "Efektifitas Komunikasi Melalui Komunikasi Primer Dan Sekunder Dalam Pembelajaran PAI Di SMP Negeri 2 Luyo Kecamatan Luyo Kabupaten Polewali Mandar".

Berdasarkan latar belakang masalah yang telah dipaparkan, maka masalah dalam penelitian ini dapat dirumuskan sebagai berikut:

1. Bagaimanakah efektifitas komunikasi primer dalam pembelajaran PAI di SMP Negeri 2 Luyo Kecamatan Luyo Kabupaten Polewali Mandar?

2. Bagaimanakah efektifitas komunikasi sekunder dalam pembelajaran PAI di SMP Negeri 2 Luyo Kecamatan Luyo Kabupaten Polewali Mandar?

Sesuai dengan rumusan masalah yang telah dikemukakan, maka tujuan penelitian ini adalah:

1. Untuk mengetahui efektifitas komunikasi primer dalam pembelajaran PAI di SMP Negeri 2 Luyo Kecamatan Luyo Kabupaten Polewali Mandar.

2. Untuk mengetahui efektifitas komunikasi sekunder dalam pembelajaran PAI di SMP Negeri 2 Luyo Kecamatan Luyo Kabupaten Polewali Mandar.

Manfaat yang diharapkan dari hasil penelitian ini adalah:

1. Bagi guru, penelitian ini diharapkan dapat bermanfaat untuk menciptakan komunikasi yang efektif di kelas sehingga antara guru dan peserta didik memiliki kesamaan makna dalam hal pelajaran, sehingga dapat meningkatkan hasil belajar peserta didik.

2. Bagi peserta didik, penelitian ini diharapkan dapat bermanfaat untuk lebih terbuka dengan guru, sehingga peserta didik mampu berkomunikasi dengan baik, serta mampu mengutarakan pemikirannya terlebih ketika ada yang belum dimengerti.

${ }^{6}$ Yosal Iriantara dan Usep Syaripudin, Komunikasi Pendidikan (Bandung: Remaja Rosdakarya, 2013), h. 84-85. 
3. Bagi pembaca, penelitian ini diharapkan dapat menjadi acuan dalam penelitian berikutnya terkait dengan efektifitas komunikasi dalam pelajaran.

\section{METODE PENELITIAN}

Jenis penelitian yang digunakan adalah penelitian deksriptif dengan pendekatan kualitatif. Sebagai penelitian deskriptif, penelitian ini mengambil masalah atau memusatkan perhatian pada masalah aktual sebagaimana adanya pada saat penelitian dilaksanakan sehingga obyek penelitian menjadi jelas, dalam hal ini berkaitan dengan komunikasi primer dan komunikasi sekunder dalam pembelajaran PAI di SMP Negeri 2 Luyo Kecamatan Luyo Kabupaten Polewali Mandar.

Sesuai judul penelitian, maka penelitian ini dilaksanakan di SMP Negeri 2 Luyo Kecamatan Luyo Kabupaten Polewali Mandar selama 3 (tiga) bulan, yaitu pada bulan Agustus 2019 sampai dengan bulan Oktober 2019. Adapun yang menjadi subjek penelitian dalam penelitian ini adalah Guru PAI dan peserta didik di SMP Negeri 2 Luyo Kecamatan Luyo Kabupaten Polewali Mandar.

Adapun jenis data yang dikumpulkan dalam penelitian ini adalah data primer dan data sekunder. Adapun yang menjadi responden atau informan yang dipilih atau ditetapkan sebagai sumber data primer dalam penelitian ini adalah guru PAI dan peserta didik di SMP Negeri 2 Luyo. Penentuan informan/responden dalam penelitian ini dilakukan dengan cara menggunakan purposive sampling, yaitu pengambilan informan/responden dengan memilih unsur-unsur tertentu saja yang dianggap penting dan mampu memberikan informasi yang dibutuhkan dalam penelitian. Data primer juga diperoleh dari observasi terhadap aktivitas guru dan peserta didik dalam kegiatan pembelajaran PAI di SMP Negeri 2 Luyo Kabupaten Polewali Mandar. Sedangkan sumber data sekundernya adalah berasal dari buku, dokumentasi, arsip dan berbagai literatur yang berkaitan dengan fokus penelitian dan dokumentasi lainya yang ada di SMP Negeri 2 Luyo Kecamatan Luyo Kabupaten Polewali Mandar.

Untuk memperoleh data yang valid dalam penelitian ini, maka metode pengumpulan data yang peneliti gunakan adalah metode observasi, wawancara dan telaah dokumen. Untuk memperlancar pengumpulan data-data dalam penelitian ini, maka peneliti menggunakan alat bantu berupa pedoman observasi, pedoman wawancara (interview) dan dokumentasi. Dalam kegiatan penelitian ini, peneliti akan hadir penuh di lapangan sebagai instrumen utama. Hadirnya peneliti di sini untuk melakukan observasi dan wawancara (interview) dengan responden/informan.

Observasi dilakukan untuk mendapatkan data yang berkaitan dengan komunikasi dalam pembelajaran PAI di SMP Negeri 2 Luyo. Peneliti melakukan observasi terhadap komponen komunikasi dalam pembelajaran yaitu guru, peserta didik, materi pelajaran, evaluasi, lingkungan belajar, dan aktivitas mengajar guru serta aktivitas belajar peserta didik yang dikelompokkan menjadi komunikasi primer dan komunikasi sekunder. Komunikasi primer yang berkaitan dengan bahasa, kial, gesture. Sedangkan komunikasi sekunder yang berkaitan dengan penggunaan media pembelajaran.

Metode wawancara difokuskan peneliti untuk menggali dan memperoleh data-data primer. Wawancara dilakukan dengan peserta didik dan guru PAI untuk menggali informasi yang mendalam 
tentang komunikasi yang berlangsung selama proses pembelajaran PAI. Responden peserta didik dipilih berdasarkan hasil belajar peserta didik yang paling tinggi, sedang dan rendah. Wawancara dilakukan secara langsung tatap muka dan secara bersama-sama, ini diharapkan dapat membuat peserta didik lebih terbuka dalam menjawab setiap pertanyaan yang diberikan.

Telaah dokumen atau dokumentasi digunakan dalam penelitian ini untuk mengetahui sejarah SMP Negeri 2 Luyo Kecamatan Luyo Kabupaten Polewali Mandar, kegiatan belajar mengajar di SMP Negeri 2 Luyo, sarana dan prasana di SMP Negeri 2 Luyo, serta informasi-informasi lainnya yang berkaitan dengan penelitian.

Sebelum dilakukan analisis data, terlebih dahulu dilakukan pengecekan data dengan teknik trianggulasi. Trianggulasi data dalam penelitian ini dilakukan untuk mengecek informasi yang telah didapatkan melalui observasi, wawancara dan dokumentasi. Selanjutnya data-data yang diperoleh dari observasi, wawancara, dan dokumentasi disusun secara kelompok sesuai dengan rumusan masalah dan kemudian dilakukan analisis dengan pendekatan kualitatif.

Analisis data dalam penelitian ini bersifat induktif, yaitu proses menganalisa yang berangkat dari fakta-fakta khusus kemudian ditarik generalisasi yang bersifat umum. Dalam konteks ini, peneliti berusaha menggali data-data dari lapangan yang selanjutnya data-data tersebut dipaparkan dan kemudian dianalisa dengan teknik induktif. Analisis data dalam penelitian ini, peneliti mengadopsi pola interaktif yang dikembangkan oleh Miles dan Huberman yang mengemukakan bahwa aktivitas dalam analisis data kualitatif dilakukan secara interakatif dan berlangsung secara terus menerus sampai tuntas, sehingga datanya sudah jenuh. Aktivitas dalam analisis ini adalah reduksi data (data reduction), penyajian data (data display), dan penarikan kesimpulan/verifikasi (conclusion drawing/verification). ${ }^{7}$

\section{HASIL PENELITIAN DAN PEMBAHASAN}

\section{A. Hasil Penelitian}

Data dalam penelitian ini diperoleh melalui observasi, wawancara, dan dokumentasi tentang efektifitas komunikasi melalui komunikasi primer dan sekunder dalam pembelajaran PAI di SMP Negeri 2 Luyo Kecamatan Luyo Kabupaten Polewali Mandar.

Observasi yang dilakukan dalam penelitian ini terbagi menjadi dua, yaitu observasi mengenai komponen komunikasi dan aktifitas belajar mengajar yang diuraikan sebagai berikut:

1. Komponen Komunikasi

Komponen komunikasi dalam pembelajaran Pendidikan Agama Islam (PAI) di SMP Negeri 2 Luyo Kecamatan Luyo Kabupaten Polewali Mandar diantaranya adalah sebagai berikut:

a. Komunikator/Pengirim Pesan

Guru merupakan seorang komunikator dalam sebuah pembelajaran. Guru memberikan sebuah pesan berupa materi pelajaran kepada peserta didik. Guru PAI di SMP Negeri 2 Luyo adalah seorang perempuan yang bernama Hasnur, S.Ag. Beliau mengajar di SMP Negeri 2 Luyo sejak tahun

${ }^{7}$ Sugiyono, Metode Penelitian Pendidikan: Pendekatan Kualitatif, Kuantitatif, dan $R \& D$ (Bandung: Alfabeta, 2015) h. 337. 
2015 lalu. Beliau merupakan sarjana agama, bidang studi yang beliau kuasai tentunya Pendidikan Agama Islam (PAI). Beliau dipercayai untuk mengajar PAI. ${ }^{8}$ Beliau mengajar PAI pada kelas VII, kelas VIII dan kelas IX karena di SMP Negeri 2 Luyo Kecamatan Luyo Kabupaten Polewali Mandar masih kekurangan guru PAI.

b. Komunikan/Penerima Pesan

Peserta didik berperan sebagai komunikan dalam proses pembelajaran PAI tersebut. Jumlah peserta didik di kelas VII SMP Negeri 2 Luyo Kecamatan Luyo Kabupaten Polewali Mandar sebanyak 24 orang, yang terdiri dari 11 laki-laki dan 13 perempuan.

c. Pesan

Pesan yang dimaksud di sisi adalah materi pelajaran yang diajarkan kepada peserta didik. Materi pelajaran yang diajarkan mengacu kepada kurikulum 2013 yang sudah diterapkan pada sekolah ini. ${ }^{9}$

d. Media

Media merupakan saluran komunikasi tempat berlalunya pesan dari komunikator kepada komunikan. Pengunaan media tidak terlepas dari proses komunikasi, media sebagai penghubung untuk menyampaikan pesan berupa materi pelajaran kepada peserta didik. Dalam penelitian ini, komunikasi dibagi menjadi dua yaitu komunikasi primer dan komunikasi sekunder berdasarkan media yang digunakan.

e. Umpan Balik/Feed Back

Umpan balik merupakan tanggapan dari peserta didik selama proses pembelajaran berlangsung. Dalam proses pembelajaran, guru memberikan tugas kepada peserta didik. Ketika peserta didik telah selesai mengerjakan tugas tersebut peserta didik diminta untuk mempertanggung jawabkannya dengan cara maju ke depan dan membacakan jawabanya, ini merupakan tanggapan yang diberikan peserta didik, yaitu mampu menyelesaikan tugas tersebut serta mampu mengkomunikasikan hasil tugas yang telah dikerjakan.

Respon lainnya yang ditunjukkan oleh peserta didik yaitu ketika guru memberikan tugas untuk merangkum, peserta didik yang mampu mengerjakan tugas dengan cepat dan benar diberikan nilai A, ini memotivasi peserta didik untuk merespon dengan mengerjakan tugas tersebut secara sungguh-sungguh. Respon peserta didik menunjukkan suatu tanda bahwa komunikasi yang berlangsung dapat dikatakan baik, sebab peserta didik mampu menjalankan tugas dari guru.

Menurut Ibu Hasnur, S.Ag bahwa:

Feed back yang dinginkan tentunya peserta didik memahami betul tentang agama yang dianutnya, dengan seperti itu maka kesadaran beragamanya akan muncul. Jika sudah seperti itu maka peserta didik belajar bukan untuk mengejar nilai tapi mencari ilmu pengetahuan sehingga siswa akan mudah mengamalkan ilmu yang dimiliki. Jika peserta didik belajar hanya ingin mencari nilai tentunya hanya sekedar mengetahui saja tetapi dalam penerapannya mereka tidak kerjakan, seperti sholat. ${ }^{10}$

f. Evaluasi

\footnotetext{
${ }^{8}$ Ibu Hasnur (Guru PAI), Wawancara (SMP Negeri 2 Luyo, 17 September 2019)

${ }^{9}$ Hasil observasi komponen komunikasi (SMP Negeri 2 Luyo, 22 Agustus 2019).

${ }^{10} \mathrm{Ibu}$ Hasnur (Guru PAI), Wawancara (SMP Negeri 2 Luyo, 17 September 2019).
} 
Evaluasi yang dilakukan dalam proses pembelajaran yaitu memberikan tugas kepada peserta didik. Guru memerintahkan peserta didik untuk menulis dalil naqli tentang sholat Jumat yaitu Qs. alJumuah: 9, dengan cara menuliskan ayat perkata beserta artinya. Ketika selesai, kemudian guru menunjuk peserta didik untuk maju ke depan dan membacakan ayat tersebut dengan tartil. Peserta didik yang mampu menyelesaikan tugas secara cepat dan benar, guru akan memberikan reward berupa nilai A. Selain itu, guru juga memerintahkan peserta didik untuk membuat rangkuman, rangkuman dibuat agar peserta didik mudah memahami materi yang disampaikan, setelah itu guru pun menunjuk peserta didik untuk mengkomunikasikan hasil rangkuman yang telah dibuat ke depan kelas. Selama proses pembelajaran, guru selalu melakukan evaluasi agar mengetahui pemahaman peserta didik. Evaluasi yang lainnya, yaitu ulangan harian, ulangan tengah semester dan ulangan akhir.

g. Efek

Efek merupakan perubahan yang terjadi pada peserta didik baik dalam aspek kognitif, yaitu peserta didik mampu memahami materi pelajaran. Efek afektif akan timbul ketika seorang mendapatkan perhatian dari orang lain maka akan menimbulkan suatu tindakan baru. Guru memberikan perhatian kepada peserta didik sehingga peserta didik akan merasa diperhatikan, hal ini juga yang akan membuat peserta didik lebih giat dalam mengikuti pembelajaran.

\section{h. Lingkungan}

Lokasi SMP Negeri 2 Luyo Kecamatan Luyo Kabupaten Polewali Mandar berhadapan langsung dengan jalan raya, sehingga suara bising dari kendaraan umum cukup terdengar sampai ke dalam sekolah ini. Sarana prasarana yang terdapat di SMP Negeri 2 Luyo ini sudah mendukung untuk membantu peserta didik melakukan proses pembelajaran. Sirkulasi udara di SMP Negeri 2 Luyo Kecamatan Luyo Kabupaten Polewali Mandar ini pun cukup baik, karena setiap kelas dilengkapi ventilasi udara yang baik. Meja guru berada di depan kelas. Ruang kelas pun dilengkapi dengan hiasan foto presiden, wakil presiden, burung garuda, dan foto para pahlawan yang dipajang di dinding. Peserta didik pun diberikan pinjaman buku paket dari perpustakaan, sehingga tidak ada lagi peserta didik yang tidak memiliki buku paket. ${ }^{11}$

2. Aktifitas Belajar Mengajar

Aktivitas belajar mengajar di SMP Negeri 2 Luyo Kecamatan Luyo Kabupaten Polewali Mandar difokuskan kepada komunikasi primer dan komunikasi sekunder yang terjadi dalam pembelajaran Pendidikan Agama Islam (PAI). Berikut ini adalah penjelasan kegiatan tersebut:

a. Aktivitas Mengajar Guru

Guru membuka pembelajaran dengan mengucapkan salam kepada peserta didik, sebelum melanjutkan materi berikutnya, guru mengajukan pertanyaan tentang materi minggu lalu, kemudian guru menjelaskan kepada peserta didik pentingnya materi pembelajaran yang akan dibahas. Dalam menjelaskan materi, guru menggunakan bahasa yang mudah dipahami. Setelah itu guru memeriksa absensi untuk mengecek kehadiran peserta didik. Guru juga memberitahu tentang tujuan

\footnotetext{
${ }^{11}$ Hasil observasi komponen komunikasi (SMP Negeri 2 Luyo, 22 Agustus 2019).
} 
pembelajaran kepada peserta didik dan meminta peserta didik untuk menuliskan kembali pada buku tulis mereka. Selanjutnya, guru menjelaskan isi materi pembelajaran.

Guru menggunakan power point untuk menjelaskan isi materi pembelajaran yang dibuat dengan warna yang berbeda sehingga membuat peserta didik lebih tertarik dan mudah mengingatnya. Selanjutnya, guru menugaskan siswa. Setelah peserta didik selesai, guru memanggil peserta didik untuk maju ke depan dan menjelaskan jawabannya. Ketika peserta didik menjelaskan jawabannya, guru mendengarkan dengan serius.

Kemampuan mendengarkan menjadi salah satu indikator komunikasi efektif, seorang guru harus bisa mendengarkan muridnya untuk melihat sejuah mana kemampuan peserta didik dalam menguasai materi pelajaran. Ekspresi guru berubah menjadi senang ketika peserta didik mampu menjawab pertanyaan dengan benar, dan guru pun memberikan pujian kepada peserta didik. Ketika menjelaskan materi pelajaran, guru melakukan tekanan-tekanan pada kalimat yang dianggap sangat penting. Guru juga memerintahkan peserta didik untuk membuat rangkuman mengenai pengertian, dalil naqli, syarat, dan lainnya.

Ketika guru memerintahkan peserta didik untuk membuat rangkuman, guru selalu mengecek peserta didik satu persatu, ini bentuk dari perhatian yang diberikan guru kepada peserta didik sehingga peserta didik merasa termotivasi dan merasa diperhatikan. Guru menutup pelajaran dengan mengucapkan salam, dan memberikan tugas kepada peserta didik untuk mengerjakan LKS.

b. Aktivitas Belajar Peserta Didik

Selama mengikuti pembelajaran peserta didik terlihat memperhatikan guru ketika menjelaskan, terutama ketika guru menggunakan power point sebagai alat bantu sehingga peserta didik lebih perhatian mengikuti pembelajaran. Komunikasi yang efektif ditandai dengan peserta didik ikut aktif dalam proses pembelajaran, ini dibuktikan dengan cara guru selalu memberikan tugas dan peserta didik diminta mempertanggung jawabkan tugas tersebut, dan ketika tugas telah selesai dikerjakan guru akan memberikan nilai A pada peserta didik yang mampu menyelesaikan tugas dengan benar dan cepat, ini menjadi motivasi tersendiri untuk peserta didik agar ikut aktif dalam pembelajaran.

Menurut guru mata pelajaran PAI (Hasnur, S.Ag) dalam wawancara dengan peneliti, Beliau mengungkapkan bahwa:

Komunikasi itu sangat penting sekali, tanpa komunikasi tidak akan bisa menyampaikan apa yang kita inginkan, bahkan komunikasi yang tidak efektif pun akan membuat tujuan pembelajaran tidak akan tercapai. Untuk menciptakan komunikasi yang efektif harus menumbuhkan kesadaran peserta didik akan pentingnya mempelajari PAI, dengan begitu peserta didik akan dengan sendirinya mengikuti pembelajaran. Untuk mengukur keefektifan komunikasi dapat dilihat dari hasil pembelajaran yang guru lakukan, apabila peserta didik paham dengan maksud guru maka komunikasinya berjalan dengan baik. Serta media sangat membantu guru dalam menjalankan proses mengajar, ini lebih mengefesinkan waktu dan juga meminimalisir ketidakpahaman peserta didik, dengan media peserta didik akan mudah memahami isi pembelajaran. ${ }^{12}$

\footnotetext{
${ }^{12} \mathrm{Ibu}$ Hasnur (Guru PAI), Wawancara (SMP Negeri 2 Luyo, 17 September 2019).
} 
Selain wawancara dengan guru mata pelajaran PAI, peneliti juga melakukan wawancara dengan peserta didik. Dalam wawancara tersebut, Peserta didik mengatakan bahwa komunikasi yang dilakukan oleh guru sudah baik, mereka mudah memahami pelajaran tersebut. Kendala yang dirasakan peserta didik itu, ketika guru memerintahkan untuk membaca al-Quran harus dengan ilmu tajwid, karena pemahaman mereka mengenai tajwid masih kurang. Selebihnya mereka tidak mengalami kendala dalam materi lainnya. Guru juga memberikan contoh-contoh yang sesuai relevan dengan pembelajaran. Selain itu peserta didik merasa senang mengikuti pelajaran PAI, mereka selalu termotivasi mengikutinya karena guru akan memberikan nilai A, jika mereka mengerjakan tugas dengan baik dan benar, serta guru juga memberikan mereka pujian jika mereka berhasil menjawab pertanyaan. Ini merupakan salah satu tanda bahwa komunikasi yang tercipta dalam pembelajaran PAI di SMP Negeri 2 Luyo Kecamatan Luyo Kabupaten Polewali Mandar berlangsung efektif, peserta didik ikut aktif dalam pembelajaran.

SMP Negeri 2 Luyo Kecamatan Luyo Kabupaten Polewali Mandar telah menerapkan kurikulum 2013 pada proses pembelajarannya. Strandar proses pembelajaran menurut kurikulum 2013 terdiri dari dua tahap, yaitu perencanaan pembelajaran dan proses pembelajaran itu sendiri yang di dalamnya terdapat kegiatan awal, kegiatan inti, dan kegiatan akhir. Proses tersebut dijabarkan sebagai berikut:

1. Perencanaan pembelajaran

Proses komunikasi pembelajaran merupakan sebuah siklus memilih apa yang akan dibelajarkan pada peserta didik hingga tahap evaluasi untuk melihat sejauh mana ketercapaian tujuan pembelajaran tersebut. Siklus tersebut dimulai ketika guru memilih apa yang dibelajarkan pada peserta didik. Tahap ini merupakan tahap Rencana Pelaksanaan Pembelajaran (RPP), dalam RPP guru menentukan materi, tujuan pembelajaran, alokasi waktu, metode, sumber belajar, bahkan penilaian yang telah disusun sesuai dengan ketentuan kurikulum 2013. Ibu Hasnur, S.Ag mengatakan bahwa Rencana Pelaksanaan Pembelajaran (RPP) dibuatnya jauh sebelum kegiatan semester ini dimulai, jadi ketika mengajar sudah tidak buat RPP lagi. ${ }^{13}$

2. Proses pembelajaran

Dalam proses pembelajaran terdapat tiga kegiatan yaitu kegiatan awal, kegiatan inti dan kegiatan penutup. Komunikasi pembelajaran terjadi dalam setiap proses pembelajaran. Pada kegiatan awal, guru membuka kegiatan pembelajaran dengan mengucapakan salam. Guru memeriksa absensi peserta didik dan menyampaikan tujuan pembelajaran. Untuk membangun komunikasi yang efektif guru selalu menyampaikan tujuan pembelajaran, diharapkan peserta didik akan lebih mudah memahaminya. Guru juga memberikan ulasan mengenai pembahasan sebelumnya, setelah itu guru masuk pada kegiatan inti proses penyampaian materi dilakukan dengan menggunakan ceramah, karena ceramah tidak dapat dipisahkan dalam proses pembelajaran.

Proses penyampaian materi pelajaran dengan menggunakan bahasa yang jelas sehingga siswa mudah memahaminya. Suara guru pun terdengar jelas hingga belakang sehingga peserta didik yang duduk dibelakang pun mampu mendengar dengan jelas. Dalam menjelaskan materi pelajaran guru

\footnotetext{
${ }^{13}$ Ibu Hasnur (Guru PAI), Wawancara (SMP Negeri 2 Luyo, 17 September 2019).
} 
tidak terbata-bata, sehingga memungkinkan peserta didik mampu memahami materi pelajaran. Guru menggunakan power point untuk menjelaskan materi pelajaran. ${ }^{14}$

Penggunaan media sangat membantu dalam proses pembelajaran. Ketika terdapat materi yang mengharuskan menulis al-Quran tidak perlu mengahabiskan waktu yang cukup banyak, hanya tinggal menampilkan lewat power point dan peserta didik akan lebih memahami makna dari kandungan al-Quran tersebut. Penggunaan media akan membuat anak lebih fokus dan tertarik untuk memperhatikan pembelajaran, dengan begitu peserta didik akan lebih memahami materi yang disampaikan oleh guru. ${ }^{15}$

Penggunaan media pembelajaran yang digunakan sebagai inovasi dalam pembelajaran agar peserta didik tidak jenuh dengan mengikuti pelajaran. Mengingat setiap peserta didik memiliki gaya belajar yang berbeda-beda maka dengan adanya media akan membantu peserta didik dalam memahami materi pelajaran. Selain itu, guru meminta peserta didik untuk memanfaatkan buku paket untuk melihat dengan jelas isi materi tersebut. Jadi, guru memberikan tugas kepada peserta didik untuk menuliskan kembali dalil naqli tersebut kedalam buku tulis. Tentunya ini juga sebagai latihan, agar peserta didik terbiasa untuk menulis ayat al-Quran.

Ketika peserta didik mengerjakan tugas tersebut, guru berkeliling untuk memeriksa tugas yang dikerjakan peserta didik, ini salah satu bentuk perhatian yang ditunjukkan guru untuk peserta didik. $^{16}$

Adanya komunikasi antarpersonal yang dibangun guru dan peserta didik dapat meningkatkan efektivitas komunikasi yang terjadi. Karena peserta didik merasa diperhatikan oleh guru sehingga keinginan peserta didik untuk menyimak pembelajaran lebih tinggi. Setelah semua peserta didik telah menyelesaikan tugasnya, kemudian guru memanggil peserta didik satu per satu untuk membacakan surah tersebut beserta artinya.

Peserta didik diminta untuk membacakan kembali surah tersebut beserta dengan artinya, guru mendengarkan serius sehingga peserta didik yang masih salah membaca surah tersebut langsung dibenarkan oleh guru. Kemampuan mendengarkan menjadi salah satu indikator komunikasi efektif, seorang guru harus bisa mendengarkan muridnya, ini bertujuan untuk melihat sejuah mana kemampuan peserta didik dalam menguasai materi pelajaran. Terlihat ekspresi wajah guru ketika peserta didik masih salah dalam membaca surah, ekspresi kekecewaan terpancar di wajah guru, tetapi ketika peserta didik membenarkan bacaannya sesuai dengan perintah guru terlihat ekspresi senang di wajah guru. ${ }^{17}$ Cara ini dilakukan guru agar peserta didik ikut terlibat dalam pembelajaran serta melatih peserta didik untuk berani mengkomunikasikan tugasnya.

Tak ada hambatan yang berarti selama proses komunikasi dalam pembelajaran tersebut. Namun kendala tersebut muncul dari pihak komunikan yaitu peserta didik yang belum memiliki kesadaran tentang pentingnya mempelajari PAI. Tentunya ini bukan hanya menjadi tanggung jawab guru di sekolah tetapi juga orang tua di rumah. Harus ada kerjasama yang berimbang antara guru dengan orang tua dalam menumbuhkan kesadaran pada diri peserta didik.

3. Evaluasi

\footnotetext{
${ }^{14}$ Hasil observasi aktivitas mengajar guru (SMP Negeri 2 Luyo, 24 Agustus 2019).

${ }^{15}$ Ibu Hasnur (Guru PAI), Wawancara (SMP Negeri 2 Luyo, 17 September 2019).

${ }^{16}$ Hasil observasi aktivitas mengajar guru (SMP Negeri 2 Luyo, 24 Agustus 2019).

${ }^{17}$ Hasil observasi aktivitas mengajar guru (SMP Negeri 2 Luyo, 24 Agustus 2019).
} 
Evaluasi dilakukan untuk melihat sejauh mana pemahaman peserta didik dalam mengikuti pembelajaran. Evaluasi sangat penting dilakukan, apabila masih ada peserta didik yang belum memahami pelajaran, guru harus membantu peserta didik tersebut sampai memahami materi pelajaran tersebut.

Evaluasi yang dilakukan untuk mengukur proses biasanya diakhir guru bertanya kepada peserta didik, atau dengan cara menunjuk satu peserta didik untuk mewakili satu deretannya. Peserta didik yang mampu menyelesaikan tugas secara cepat dan benar guru akan memberikan reward berupa nilai A. Untuk mengukur tindak lanjut tentunya dilihat dari nilai ulangan, yaitu nilai ulangan harian, nilai ulangan tengah semester dan ulangan akhir. ${ }^{18}$

Menurut guru mata pelajaran PAI (Hasnur, S.Ag) dalam wawancara dengan peneliti, Beliau mengungkapkan bahwa:

Hasil belajar peserta didik dapat dikatakan cukup baik, karena tidak ada peserta didik yang mendapatkan nilai kurang dari 40. Ini menandakan bahwa peserta didik telah mampu memahami materi pelajaran walaupun hanya $40 \%$ saja. $^{19}$

Komunikasi efektif terjadi bila pembelajaran berlangsung secara dua arah dengan melibatkan peserta didik. Guru berusaha untuk melibatkan peserta didik dalam pembelajaran dengan cara memberikan tugas dan peserta didik harus mampu mengkomunikasikan tugas tersebut. Guru PAI juga memberikan perhatian kepada peserta didik, guru dikenal sebagai sosok yang tegas. Pemberian perhatian ini akan membuat peserta didik senang dalam mengikuti pembelajaran.

\section{B. Pembahasan}

\section{Efektifitas Komunikasi Primer dalam Pembelajaran PAI di SMP Negeri 2 Luyo Kecamatan Luyo Kabupaten Polewali Mandar}

Komunikasi pembelajaran merupakan sebuah siklus yang dimulai ketika guru memilih apa yang akan dibelajarkan pada peserta didik hingga tahap evaluasi untuk melihat sejauh mana ketercapaian tujuan pembelajaran tersebut. ${ }^{20}$ Komunikasi dapat terjadi apabila komponen-komponen komunikasi telah terpenuhi, begitu juga dalam pembelajaran, komunikasi akan terjadi apabila komponen komunikasi telah terpenuhi.

Komunikasi primer adalah proses penyampaian materi pelajaran kepada peserta didik dengan menggunakan lambang bahasa, kial, isyarat, gambar, warna, dan lain sebagainya. Dalam proses pembelajaran PAI di SMP Negeri 2 Luyo Kecamatan Luyo Kabupaten Polewali Mandar, guru menggunakan lambang bahasa yaitu ceramah untuk menjelaskan materi kepada peserta didik.

Selain itu guru PAI tidak lupa untuk memberikan perhatian kepada peserta didik dengan cara memeriksa tugas peserta didik satu persatu, perhatian ini ditunjukkan agar peserta didik lebih termovitasi dalam mengikuti pembelajaran. Pembelajaran PAI di SMP Negeri 2 Luyo Kecamatan Luyo Kabupaten Polewali Mandar dilaksanakan di kelas secara tatap muka langsung antara guru dengan peserta didik.

\footnotetext{
${ }^{18}$ Hasil observasi aktivitas mengajar guru (SMP Negeri 2 Luyo, 24 Agustus 2019).

${ }^{19}$ Ibu Hasnur (Guru PAI), Wawancara (SMP Negeri 2 Luyo, 17 September 2019).

${ }^{20}$ Yosal Iriantara dan Urep Syaripudin, Komunikasi Pendidikan, h. 74.
} 
Untuk membangun komunikasi yang efektif, ada lima aspek yang harus diperhatikan, yaitu:

a. Kejelasan

Komunikasi harus menggunakan bahasa dan mengemas secara jelas, sehingga mudah diterima dan dipahami oleh komunikan.

b. Ketepatan

Ketepatan ini menyangkut penggunaan bahasa yang benar dan kebenaran informasi yang disampaikan.

c. Konteks

Konteks atau situasi maksudnya adalah bahasa dan informasi yang disampaikan harus sesuai dengan keadaan dan lingkungan dimana komunikasi itu terjadi.

d. Alur

Bahasa dan informasi yang disajikan harus disusun dengan alur atau sistematika yang jelas, sehingga pihak yang menerima informasi cepat tanggap. ${ }^{21}$

Guru menjelaskan materi pelajaran dengan bahasa yang mudah dipahami sehingga peserta didik mampu mengerti maksud dari ucapan guru tersebut. Selain itu, suara guru juga terdengar jelas dan kencang sehingga peserta didik yang duduk di bagian belakang pun masih dapat mendengar suara guru ketika menjelaskan. ${ }^{22}$ Dalam menjelaskan materi pun guru sangat memperhatikan intonasi suaranya, sehingga guru memberikan tekanan-tekanan nada pada kalimat yang dianggapnya penting.

Ketika guru memberikan tugas kepada peserta didik untuk menuliskan kembali dalil naqli tentang sholat Jumat dan merangkum materi tentang sholat Jumat, guru selalu mengelilingi peserta didik satu persatu untuk mengecek tugas yang sedang dikerjakan oleh peserta didik. ${ }^{23}$ Perhatian ini ditunjukkan untuk membangun komunikasi antarpersonal antara guru dengan peserta didik, dengan begitu peserta didik merasa diperhatikan sehingga peserta didik lebih giat dalam mengikuti pelajaran.

Ketika peserta didik sedang mempertanggung jawabkan tugasnya guru menjadi pendengar yang baik, dengan begitu setiap kesalahan peserta didik dapat mudah diketahui dan diperbaiki. Ekspresi guru akan menguatkan pesan komunikasi yang terjadi, ini telihat pada guru, ketika peserta didik belum bisa membaca al-Quran sesuai dengan ilmu tajwidnya, guru menampakkan kekecewaan terhadap peserta didik. Sebab, guru beranggapan bahwa untuk anak SMP. seharusnya bacaan alQuran dan pemahaman tajwid sudah di luar kepala. Tetapi, pada kenyataannya tajwid merupakan salah satu materi yang sulit dipelajari menurut peserta didik, karena peserta didik merasa guru belum menjelaskan secara detail tentang ilmu tajwid kepada mereka. Peserta didik yang masih salah dalam membaca kemudian dibenarkan oleh guru. Terlihat jelas raut muka guru menjadi senang bila peserta didik berhasil membaca dengan benar.

Guru selalu berusaha untuk menciptakan komunikasi yang efektif dengan cara melibatkan peserta didik dalam pembelajaran. Cara lain yang digunakan guru untuk melibatkan peserta didik yaitu dengan memberikan kesempatan kepada peserta didik untuk bertanya, tetapi kebanyakan dari mereka tidak memanfaatkan kesempatan tersebut untuk bertanya karena merasa malu, dan tidak ada yang merasa perlu dipertanyakan.

\footnotetext{
${ }^{21}$ Abdul Majid, Strategi Pembelajaran (Cet. 3; Bandung: Remaja Rosdakarya, 2014), h. 291.

${ }^{22}$ Peserta didik, Wawancara (SMP Negeri 2 Luyo, 22 September 2019).

${ }^{23}$ Hasil observasi aktivitas mengajar guru (SMP Negeri 2 Luyo, 24 Agustus 2019).
} 
Berdasarkan uraian di atas maka dapat disimpulkan bahwa komunikasi primer yang terjadi dalam pembelajaran PAI di SMP Negeri 2 Luyo Kecamatan Luyo Kabupaten Polewali Mandar terjadi secara langsung, yaitu guru dan peserta didik bertatap muka dengan menggunakan lambang bahasa, kial, isyarat, gambar, warna, dan lain sebagainya dalam proses pembelajaran tersebut. Dengan kondisi seperti ini maka pesan berupa materi pelajaran dapat tersampaikan dengan baik kepada peserta didik. Artinya komunikasi primer yang terjadi dalam pembelajaran PAI di SMP Negeri 2 Luyo Kecamatan Luyo Kabupaten Polewali Mandar adalah terlaksana secara efektif. Hal ini ditandai dengan adanya proses:

a. Guru menjelaskan materi pelajaran dengan bahasa yang mudah dipahami.

b. Memberikan motivasi kepada peserta didik.

c. Guru kreatif dalam tata kelas.

d. Guru bersikap ekspresif sebagai penguat komunikasi.

e. Komunikasi yang dua arah.

\section{Efektifitas Komunikasi Sekunder dalam Pembelajaran PAI di SMP Negeri 2 Luyo Kecamatan Luyo Kabupaten Polewali Mandar}

Komunikasi sekunder adalah proses penyampaian materi pelajaran kepada peserta didik dengan menggunakan alat sebagai media kedua setelah lambang bahasa sebagai media pertama. Media tersebut digunakan untuk memperjelas komunikasi yang terjadi dalam proses pembelajaran. Media tersebut dapat berupa buku paket, LKS, power point, video, al-Quran, dan lain sebagainya. Komunikasi yang efektif ditandai dengan:

a. Pemahaman.

b. Kesenangan.

c. Memengaruhi sikap.

Kurikulum 2013 yang diterapkan pada SMP Negeri 2 Luyo Kecamatan Luyo Kabupaten Polewali Mandar mengharuskan guru untuk menghadirkan media sebagai alat bantu dalam proses pembelajaran, begitu pun pada materi PAI tersebut. Guru menggunakan power point sebagai alat untuk menjelaskan dalil naqli. Guru juga menggunakan buku paket sebagai media pembelajaran agar peserta didik dapat melihat dengan jelas isi materi yang dibahas.

Penggunaan media merupakan cara yang dilakukan guru untuk meningkatkan semangat belajar pada peserta didik. Pada awal penggunaan power point tersebut, dapat terlihat sikap perhatian peserta didik lebih terfokus dibandingkan sebelum guru menggunakan media tersebut. Ketika guru menggunakan power point terlihat sekali peserta didik lebih antusias dalam mengikuti pembelajaran, serta dengan menggunakan power point juga akan mempermudah peserta didik dalam memahami materi tersebut.

Media sangat membantu guru dalam proses pembelajaran, karena setiap peserta didik memiliki kecerdasan yang berbeda-beda, untuk mengatasi keterbatasan peserta didik dalam belajar diharapkan penggunaan media dapat membantu peserta didik selama pembelajaran berlangsung.

Berdasarkan uraian di atas maka dapat disimpulkan bahwa komunikasi sekunder yang terjadi dalam pembelajaran PAI di SMP Negeri 2 Luyo Kecamatan Luyo Kabupaten Polewali Mandar terjadi secara langsung, yaitu guru dan peserta didik bertatap muka dengan menggunakan alat sebagai media kedua dalam proses pembelajaran tersebut. Dengan kondisi seperti ini maka pesan berupa materi 
pelajaran dapat tersampaikan dengan baik kepada peserta didik. Artinya komunikasi sekunder yang terjadi dalam pembelajaran PAI di SMP Negeri 2 Luyo Kecamatan Luyo Kabupaten Polewali Mandar telah terlaksana secara efektif. Hal ini ditandai dengan:

a. Guru menggunakan power point sebagai alat bantu dalam komunikasi.

b. Tersedianya buku paket yang memadai sehingga dapat digunakan oleh guru dan peserta didik.

c. Adanya penggunaan LKS dalam proses pembelajaran.

\section{PENUTUP}

\section{A. Simpulan}

Berdasarkan hasil penelitian dan pembahasan yang telah dipaparkan sebelumnya, maka dapat disimpulkan bahwa:

1. Komunikasi primer yang terjadi dalam pembelajaran PAI di SMP Negeri 2 Luyo Kecamatan Luyo Kabupaten Polewali Mandar telah terlaksana secara efektif yang ditandai dengan adanya proses:

a. Guru menjelaskan materi pelajaran dengan bahasa yang mudah dipahami.

b. Memberikan motivasi kepada peserta didik.

c. Guru kreatif dalam tata kelas.

d. Guru bersikap ekspresif sebagai penguat komunikasi.

e. Komunikasi yang dua arah.

2. Komunikasi sekunder yang terjadi dalam pembelajaran PAI di SMP Negeri 2 Luyo Kecamatan Luyo Kabupaten Polewali Mandar telah terlaksana secara efektif yang ditandai dengan:

a. Guru menggunakan power point sebagai alat bantu dalam komunikasi.

b. Tersedianya buku paket yang memadai sehingga dapat digunakan oleh guru dan peserta didik. c. Adanya penggunaan LKS dalam proses pembelajaran.

\section{B. Saran} berikut:

Adapun saran yang dapat dikemukakan berdasarkan hasil penelitian ini adalah sebagai

1. Kepala sekolah sebagai pimpinan dalam sekolah hendaknya memperhatikan fasilitas yang ada, agar fasilitas yang mengalami kerusakan segera diperbaiki.

2. Guru hendaknya lebih meningkatkan kemampuan komunikasi antar personal dengan begitu guru akan lebih mudah memahamai peserta didik dan mengetahui permasalahan yang ada pada diri peserta didik. Dengan begitu, guru akan mampu memaksimalkan komunikasi yang terjadi.

3. Bagi peserta didik, hendaknya lebih aktif lagi dalam mengikuti proses pembelajaran, dan jangan malu untuk bertanya apabila guru memberikan waktu untuk bertanya. 


\section{DAFTAR PUSTAKA}

Abdulhak, Ishak dan Deni Darmawan. Teknologi Pendidikan. Bandung: Remaja Rosdakarya, 2015. Arikunto, Suharsimi. Prosedur Penelitian Suatu Pendekatan Praktik. Jakarta: Rineka Cipta, 2013. Cangara, Hafied. Pengantar Ilmu Komunikasi. Jakarta: Raja Grafindo Persada, 2012.

Danim, Sudarwan. Menjadi Peneliti Kualitatif. Bandung: Pustaka Setia, 2014.

Effendy, Onong Uchjana. Ilmu Teori dan Filsafat Komunikasi. Bandung: CA Publisher, 2010.

Effendy, Onong Uchjana. Dinamika Komunikasi, Cet. 13. Bandung: Remaja Rosdakarya, 2011.

Effendy, Onong Uchjana. Ilmu Komunikasi Teori dan Praktek, Cet. 21. Bandung: Remaja Rosdakarya, 2013.

Engkoswara dan Aan Komariah. Administrasi Pendidikan. Bandung: Alfabeta, 2012.

Furchan, Arif. Pengantar Penelitian dalam Pendidikan. Yogyakarta: Pustaka Pelajar, 2011.

Habibullah, Ahmad. Efektivitas Pokjawas dan Kinerja Pengawas Pendidikan Agama Islam. Cet. 1. Jakarta: Pena Citasatria, 2008.

Iriantara, Yosal dan Usep Syaripudin. Komunikasi Pendidikan. Bandung: Remaja Rosdakarya, 2013.

Jihad, Asep dan Abdul Haris. Evaluasi Pembelajaran. Yogyakarta: Multi Pressindo, 2012.

Mahmud. Metode Penelitian Pendidikan. Bandung: Pustaka Setia, 2011.

Majid, Abdul. Strategi Pembelajaran, Cet. 3. Bandung: Remaja Rosdakarya, 2014.

Moleong, Lexy J. Metodologi Penelitian Kualitatif. Bandung: Remaja Rosdakarya, 2013.

Muhammad, Arni. Komunikasi Organisasi. Jakarta: Bumi Aksara, 2009.

Munadi, Yudhi. Media Pembelajaran Sebuah Pendekatan Baru. Jakarta: Gaung Persada Press, 2012.

Naim, Ngainun. Dasar-Dasar Komunikasi Pendidikan. Jogjakarta: Ar-Ruzz Media, 2011.

Purwanto. Instrumen Penelitian Sosial dan Pendidikan. Yogyakarta: Pustaka Pelajar, 2010.

Rianto, Yatim. Paradigma Baru Pembelajaran, Sebagai Referensi bagi Pendidik dalam Implementasi Pembelajaran yang Efektif dan Berkualitas. Jakarta: Prenada Media Group, 2009.

Rosyada, Dede. Paradigma Pendidikan Demokratis. Cet. 22. Jakarta: Kencana Prenamedia Group, 2014.

Roudhonah. Ilmu Komunikasi. Jakarta: Lembaga Penelitian UIN Jakarta, 2014.

Setyosari, Punaji. Metode Penelitian Pendidikan dan Pengembangan, Cet. 3. Jakarta: Kencana Prenadamedia Group, 2013.

Siregar, Eveline dan Hartini Nara. Teori Belajar dan Pembelajaran. Bogor: Ghalia Indonesia, 2011.

Sugiyono. Metode Penelitian Pendidikan: Pendekatan Kualitatif, Kuantitatif, dan R \& D. Bandung: Alfabeta, 2015.

Susanto, Ahmad. Teori Belajar dan Pembelajaran di Sekolah Dasar. Jakarta: Kencana Prenada Media Group, 2014.

Susilo, Madya Eko. Dasar-Dasar Pendidikan. Semarang: Effahar Offset, 2010.

Thobroni, Muhammad dan Arif Mustofa, Belajar dan Pembelajaran Pengembangan Wacana dan Praktik Pembelajaran dalam Pembangunan Nasional. Jogjakarta: Ar-Ruzz Media, 2012. 
Warsita, Bambang. Tekonologi Pembelajaran Landasan dan Aplikasinya. Jakarta: Rineka Cipta, 2011. 